\title{
Papers
}

\section{Cholinesterase inhibitors for patients with Alzheimer's disease: systematic review of randomised clinical trials}

\begin{abstract}
Objectives Pharmacological treatment of Alzheimer's disease focuses on correcting the cholinergic deficiency in the central nervous system with cholinesterase inhibitors. Three cholinesterase inhibitors are currently recommended: donepezil, rivastigmine, and galantamine. This review assessed the scientific evidence for the recommendation of these agents. Data sources The terms "donepezil", "rivastigmine", and "galantamine", limited by "randomized-controlled-trials" were searched in Medline (1989-November 2004), Embase (1989-November 2004), and the Cochrane Database of Systematic Reviews without restriction for language. Study selection All published, double blind, randomised controlled trials examining efficacy on the basis of clinical outcomes, in which treatment with donepezil, rivastigmine, or galantamine was compared with placebo in patients with Alzheimer's disease, were included. Each study was assessed independently, following a predefined checklist of criteria of methodological quality.

Results 22 trials met the inclusion criteria. Follow-up ranged from six weeks to three years. 12 of 14 studies measuring the cognitive outcome by means of the 70 point Alzheimer's disease assessment scale-cognitive subscale showed differences ranging from 1.5 points to 3.9 points in favour of the respective cholinesterase inhibitors. Benefits were also reported from all 12 trials that used the clinician's interview based impression of change scale with input from caregivers. Methodological assessment of all studies found considerable flaws-for example, multiple testing without correction for multiplicity or exclusion of patients after randomisation.

Conclusion Because of flawed methods and small clinical benefits, the scientific basis for recommendations of cholinesterase inhibitors for the treatment of Alzheimer's disease is questionable.
\end{abstract}

\section{Introduction}

Currently the three cholinesterase inhibitors donepezil, rivastigmine, and galantamine are widely recommended for clinical use. The National Institute for Clinical Excellence (NICE, now National Institute for Health and Clinical Excellence), for example, says in its guidance for treatment of Alzheimer's disease that the three drugs should be made available in the NHS as one component of the management of people with mild and moderate Alzheimer's disease. ${ }^{1}$ The American Academy of Neurology also recommends cholinesterase inhibitors, although the average benefit seems small. ${ }^{2}$ The rationale for these recommendations is that evidence from randomised controlled trials has shown that all three drugs have beneficial effects on cognitive and global outcome measures. However, cholinesterase inhibitors are not widely prescribed. In Germany, donepezil, rivastigmine, and galantamine account for $10 \%$ of all antidementia drugs prescribed in 2003 . $^{3}$ The gap between multiple recommendations of these agents and their lack of use in daily clinical practice prompted us to review all available randomised controlled trials. The objective of this review is to explore the scientific evidence for the clinical use of donepezil, rivastigmine, and galantamine.

\section{Methods}

We searched the terms "donepezil", "rivastigmine", and "galantamine", limited by "randomized-controlled-trials" in Medline (1989-November 2004), Embase (1989-November 2004), and the Cochrane Database of Systematic Reviews, without restriction for language. Additionally we checked the bibliographical data of all included publications for further studies. We included all papers presenting original data of randomised, double blind, placebo controlled trials with donepezil, rivastigmine, or galantamine in patients with Alzheimer's disease and excluded trials that did not examine clinical outcomes or focused on vascular dementia. As the aim of our review was to explore the scientific evidence for the clinical benefits claimed for cholinesterase inhibitors and not to compare the benefits of the various cholinesterase inhibitors with each other, we did not include head to head comparisons in the analysis. Three of the authors (HK, TZ, HPBB) read each of the studies that met the inclusion criteria and assessed them independently, following a predefined checklist of criteria of methodological quality that was partly related to the CONSORT statement $^{4}$ (table A on bmj.com). Some items of the checklist relate to findings, others to the study design, but we considered all to be important for a comprehensive interpretation of the results. We discussed every trial in detail, and at the end of the discussion process a joint assessment of each trial was achieved.

\section{Results}

Our literature search yielded a total of 412 references, of which 19 publications met the inclusion criteria. In addition we reviewed the bibliographies of the identified studies and of all available reviews for further studies, which yielded three additional papers. We identified 12 original publications of randomised controlled trials on donepezil, ${ }^{5-16}$ five on rivastigmine, ${ }^{17-21}$ and five on galantamine. ${ }^{22-26}$ Table $\mathrm{B}$ on bmj.com shows the main characteristics and results of these 22 randomised controlled trials.

The duration of treatment varied between six weeks ${ }^{9}$ and three years. ${ }^{15}$ The number of patients included per study varied

A checklist of criteria of methodological quality and results reported in the 22 trials analysed are on bmj.com 
between $27^{21}$ and $978 .{ }^{24}$ All studies included patients with an established diagnosis of probable or possible Alzheimer's disease, according to the National Institute of Neurological and Communicative Disorders and Stroke-Alzheimer Disease and Related Disorders Association, ${ }^{27}$ with one exception where a DSM-IV diagnosis of dementia was used for inclusion. ${ }^{15}$ In eight of the 22 trials, one primary efficacy measurement was used. . $^{12-1416172126}$ The remaining 14 trials combined several instruments to assess efficacy of treatment or performed multiple analyses by using the same instrument.

\section{Assessment tools used}

Fourteen of 22 trials used the Alzheimer's disease assessment

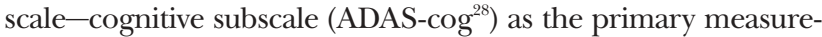
ment of efficacy. ${ }^{5-10}$ 18-20 22-26 This is a psychometric scale consisting of 11 items that evaluate selected aspects of memory, orientation, attention, language, reasoning, and carrying out instructions. Its score ranges from 0 (no impairment) to 70 (very severe impairment). In 12 of the 14 trials that used the scale, significant differences between cholinesterase inhibitor and placebo groups were reported, always favouring the treatment groups. ${ }^{5-10} 1822-26$ The mean differences between treatment and placebo groups ranged from 1.5 points to 3.9 points.

In 12 trials, the clinician's interview based impression of change scale with caregiver input (CIBIC-plus ${ }^{29}$ ) was used to assess efficacy. ${ }^{6-8} 11$ 18-25 This instrument uses information obtained during an independent clinical interview to assess disease severity and progression. A blinded clinician conducts interviews with patient and caregiver. The severity of the disease is rated at baseline and at subsequent visits. Change from baseline is scored by using a 7 point Likert-type scale, in which 1 represents marked improvement, 4 no change, and 7 marked worsening. Only full scores from 1 to 7 are used.

The differences on the CIBIC-plus scale between intervention and control groups were calculated in various manners in the trial reports. In five trials, differences of mean values between groups were calculated. ${ }^{6711820}$ In all five trials, significant benefits of the cholinesterase inhibitor were found; differences ranged from 0.26 points to 0.54 points. Eleven trials compared proportions of patients with a benefit on the CIBIC-plus scale in

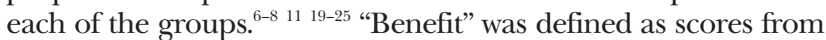
$1-3$, or 1-4-that is, the cut-off point for "benefit" was defined in different ways in the various trials. In all 11 trials, significant differences were reported in at least one of the treatment groups compared with placebo-again favouring treatment with cholinesterase inhibitors. However, in five trials ${ }^{7} 1922{ }^{24}{ }^{25}$ statistical significance vanished in all dose groups after multiplicity has been corrected for, or after considering exclusion of patients in a worst case scenario.

In 10 trials, other instruments were used to evaluate the primary end point(s). In the trial reported by Mohs et al, ${ }^{12}$ the primary end point was time in days to reach clinically evident functional decline. Donepezil extended the median time to clinically evident functional decline by five months compared with placebo. The AD2000 Collaborative Group ${ }^{15}$ used as primary end points entry to institutional care and progression of disability. No significant differences were seen in either primary end point.

Tariot et $\mathrm{al}^{13}$ used the neuropsychiatric inventory ${ }^{30}{ }^{31}$ as their endpoint measure. No difference between the donepezil and placebo group was found. Holmes et $\mathrm{al}^{16}$ also used the neuropsychiatric inventory as their endpoint measure. The results show a negative effect of withdrawal of donepezil. Winblad et $\mathrm{al}^{14}$ used the Gottfries-Brane-Steen scale ${ }^{32}$ and found no difference between donepezil and placebo. In three trials, ${ }^{5}{ }^{10}{ }^{17}$ efficacy of treatment was assessed by means of the clinical global impression of change $\left(\right.$ CGIC $^{33}$ ) scale, which is similar to the CIBIC-plus scale. Agid et $\mathrm{al}^{17}$ reported a difference between the $6 \mathrm{mg}$ rivastigmine and the control group, but significance was lost after correction for multiplicity. Rogers et $\mathrm{al}^{5}$ found no difference, whereas Homma et $\mathrm{al}^{10}$ found a significant difference favouring donepezil.

Corey-Bloom et $\mathrm{al}^{18}$ and Rösler et $\mathrm{al}^{20}$ used the progressive deterioration scale $\left(\mathrm{PDS}^{34}\right)$ as their primary outcome measure. In both trials, significant differences favouring rivastigmine were reported. In the study by Rösler et al, ${ }^{20}$ significance was lost after correction for multiplicity.

\section{Methodological quality of the trials}

Assessment of methodological quality of the 22 randomised controlled trials brought to attention numerous shortcomings (tables 1 and 2).

A common shortcoming is the use of several "primary end points without correction for multiple comparisons (see note in table 1). After correction, two of the five trials on rivastigmine do not show any significant benefit on primary endpoint measures any more. ${ }^{17} 19$

\section{Missing intention to treat analysis}

Another shortcoming is a missing intention to treat analysis, as in 15 of the 22 trials patients were excluded from analysis after randomisation (table 1, "Missing patients," 7 9-12 141719 20 22-26). In four trials, the number of participants included in endpoint analyses in each group was not reported at all or only partially. ${ }^{5} 81315$ Consequently, in these four trials the dimension of potential bias emerging through exclusion of patients cannot even be estimated. Depending on the results, exclusion of patients might become very important when mean differences are calculated between treatment groups, because exclusion of only a few patients with extreme results might change the average results considerably. Unfortunately no information is provided in the reports that would allow the reader to assess the impact of excluding patients after randomisation. Furthermore, the calculation of means might be misleading even if patients are not excluded-for example, if a small proportion of patients benefits largely from treatment, the mean value might indicate an improvement even if treatment is slightly harmful for most.

\section{Incomplete data}

The handling of incomplete data (dropouts) constitutes another important problem. In at least eight of the trials ${ }^{6-8} 1623{ }^{24} 25-26$ the last observation carried forward (LOCF) method was used to include dropouts into endpoint analyses. This means that the last evaluation before dropout is defined as the endpoint measure. Since Alzheimer's disease is a progressive illness, early discontinuation of treatment because of side effects will pretend a reduced progression of the disease in endpoint analyses using last observation carried forward. In five trials using this method, ${ }^{67232526}$ dropout rates tended to be considerably higher in the treatment groups, which must have biased the results substantially. But even if dropout rates are equal in treatment and placebo groups, knowledge of dropout time is important to estimate possible bias. However, the exact time of dropouts is reported in none of the trials.

Different design and methodological flaws

Three studies need to be discussed separately as their design or methodological flaws differ from most of the reviewed trials. 
Table 1 Methodological shortcomings of 12 randomised controlled trials on donepezil

\begin{tabular}{|c|c|c|c|c|c|c|c|c|}
\hline Author and year & Dose & $\begin{array}{l}\text { Imbalance of } \\
\text { groups at } \\
\text { baseline with } \\
\text { regard to }\end{array}$ & $\begin{array}{c}\% \text { of missing patients in } \\
\text { endpoint } \\
\text { analyses- } \\
\text { cholinesterase inhibitor } \\
\text { (placebo) }^{*}\end{array}$ & $\begin{array}{l}\text { Missing } \\
\text { information in } \\
\text { publication }\end{array}$ & $\begin{array}{c}\text { No correction for } \\
\text { multiple } \\
\text { comparisons } †\end{array}$ & $\begin{array}{l}\text { Calculation of mean } \\
\text { values may bias results }\end{array}$ & $\begin{array}{c}\text { Missing } \\
\text { information on } \\
\text { blinding in report }\end{array}$ & $\begin{array}{c}\text { Other } \\
\text { shortcomings }\end{array}$ \\
\hline \multirow[t]{3}{*}{ Rogers et al $1996^{5}$} & $1 \mathrm{mg}$ & Weight and height & $\begin{array}{c}\text { CGIC-2 (0) } \\
\text { ADAS-cog-not reported }\end{array}$ & \multirow{3}{*}{$\begin{array}{l}\text { ADAS-cog: No of } \\
\text { patients at end } \\
\text { point }\end{array}$} & \multirow[t]{3}{*}{$\begin{array}{c}\text { Correct: } 1 \\
\text { significant result }\end{array}$} & \multirow[t]{3}{*}{ ADAS-cog } & \multirow[t]{3}{*}{ Yes } & \multirow[t]{3}{*}{$\begin{array}{l}\text { Inconsistent } \\
\text { reportsł }\end{array}$} \\
\hline & $3 \mathrm{mg}$ & - & ADAS-cog一not reported & & & & & \\
\hline & $5 \mathrm{mg}$ & - & $\begin{array}{c}\text { CGIC-3 (0) } \\
\text { ADAS-cog-not reported }\end{array}$ & & & & & \\
\hline \multirow[t]{2}{*}{ Rogers et al $1998 a^{6}$} & $5 \mathrm{mg}$ & - & $\begin{array}{l}\text { ADAS-cog-1 (2) } \\
\text { CIBIC-plus-3 (2) }\end{array}$ & \multirow[t]{2}{*}{-} & \multirow[t]{2}{*}{-} & \multirow[t]{2}{*}{$\begin{array}{l}\text { ADAS-cog } \\
\text { CIBIC-plus }\end{array}$} & \multirow[t]{2}{*}{$\begin{array}{c}\text { Exception: } \\
\text { CIBIC-plus raters }\end{array}$} & \multirow{2}{*}{$\begin{array}{c}\text { Different dropout } \\
\text { rates }(\mathrm{P}<0.05) \text { : } \\
\text { placebo } 7 \% \text {; } \\
10 \mathrm{mg}: 18 \% ; \\
\text { last observation } \\
\text { carried forward }\end{array}$} \\
\hline & $10 \mathrm{mg}$ & & $\begin{array}{l}\text { ADAS-cog-2 (2) } \\
\text { CIBIC-plus-4 (2) }\end{array}$ & & & & & \\
\hline \multirow[t]{2}{*}{ Rogers et al $1998 b^{7}$} & $5 \mathrm{mg}$ & - & $\begin{array}{l}\text { ADAS-cog-1 }(6) \\
\text { CIBIC-plus-3 (6) }\end{array}$ & \multirow[t]{2}{*}{-} & \multirow[t]{2}{*}{-} & \multirow[t]{2}{*}{$\begin{array}{l}\text { ADAS-cog } \\
\text { CIBIC-plus }\end{array}$} & \multirow[t]{2}{*}{$\begin{array}{c}\text { Exception: } \\
\text { CIBIC-plus raters }\end{array}$} & \multirow{2}{*}{$\begin{array}{l}\text { Different dropout } \\
\text { rates }(\mathrm{P}<0.05) \text { : } \\
\text { placebo } 20 \% \text {; } \\
10 \mathrm{mg}: 32 \% \text {; } \\
\text { last observation } \\
\text { carried forward }\end{array}$} \\
\hline & $10 \mathrm{mg}$ & Age & $\begin{array}{l}\text { ADAS-cog-5 (6) } \\
\text { CIBIC-plus-5 (6) }\end{array}$ & & & & & \\
\hline \multirow[t]{2}{*}{ Burns et al $1999^{8}$} & $5 \mathrm{mg}$ & \multirow[t]{2}{*}{-} & \multirow[t]{2}{*}{ Not reported } & \multirow{2}{*}{$\begin{array}{l}\text { ADAS-cog and } \\
\text { CIBIC-plus: No of } \\
\text { patients at end } \\
\text { point }\end{array}$} & \multirow[t]{2}{*}{$\begin{array}{c}\text { Correct: } 3 \\
\text { significant results }\end{array}$} & \multirow[t]{2}{*}{ ADAS-cog } & \multirow[t]{2}{*}{ Yes } & \multirow[t]{2}{*}{$\begin{array}{l}\text { Last observation } \\
\text { carried forward }\end{array}$} \\
\hline & $10 \mathrm{mg}$ & & & & & & & \\
\hline $\begin{array}{l}\text { Greenberg et al } \\
2000^{9} \\
\end{array}$ & $5 \mathrm{mg}$ & - & ADAS-cog-20 (20) & - & - & ADAS-cog & - & $\begin{array}{c}\text { Observed cases } \\
\text { analysis only } \\
\end{array}$ \\
\hline Homma et al $2000^{10}$ & $5 \mathrm{mg}$ & ADAS-cog & $\begin{array}{l}\text { ADAS-cog-7 (14) } \\
\text { J-CGIC-2 (2) }\end{array}$ & $\begin{array}{c}\text { Baseline } \\
\text { characteristics of } \\
\text { intention to treat } \\
\text { population }\end{array}$ & - & ADAS-cog & Yes & - \\
\hline Feldman et al $2001^{11}$ & $10 \mathrm{mg}$ & - & CIBIC-plus-3 (0) & - & - & CIBIC-plus & Yes & Yes \\
\hline Mohs et al $2001^{12}$ & $10 \mathrm{mg}$ & - & $\begin{array}{l}\text { Dropout rate-28 (26) } \\
\text { Missing patients in } \\
\text { intention to treat } \\
\text { population-3 (4) }\end{array}$ & $\begin{array}{l}\text { Some data } \\
\text { reported only up } \\
\text { to week } 48\end{array}$ & - & - & Yes & $\begin{array}{l}\text { Inconsistent } \\
\text { reportł }\end{array}$ \\
\hline Tariot et al $2001^{13}$ & $10 \mathrm{mg}$ & Weight & Not reported & $\begin{array}{l}\text { Neuropsychiatric } \\
\text { inventory - } \\
\text { nursing home } \\
\text { version: No at end } \\
\text { point }\end{array}$ & - & $\begin{array}{c}\text { Neuropsychiatric } \\
\text { inventory - nursing home } \\
\text { version }\end{array}$ & Yes & $\begin{array}{l}\text { Inconsistent } \\
\text { reportł }\end{array}$ \\
\hline Winblad et al $2001^{14}$ & $10 \mathrm{mg}$ & Sex & $\begin{array}{l}\text { Gottfries-Brane-Steen } \\
\text { scale-3 (0) }\end{array}$ & - & - & $\begin{array}{l}\text { Gottfries-Brane-Steen } \\
\text { scale }\end{array}$ & Yes & $\begin{array}{l}\text { Inconsistent } \\
\text { reportł }\end{array}$ \\
\hline $\begin{array}{l}\text { AD2000 } \\
\text { Collaborative } \\
\text { Group 2004 }\end{array}$ & $\begin{array}{c}5 \mathrm{mg} \text { or } \\
10 \mathrm{mg}\end{array}$ & - & $\begin{array}{l}\text { Not reported adequately } \\
\text { for the Bristol activities of } \\
\text { daily living scale }\end{array}$ & $\begin{array}{l}5 \mathrm{mg} \text { and } 10 \mathrm{mg} \\
\text { not analysed } \\
\text { separately }\end{array}$ & - & - & - & $\begin{array}{c}\text { Diverse problems, } \\
\text { no clear duration } \\
\text { of study, double } \\
\text { randomisation }\end{array}$ \\
\hline Holmes et al $2004^{16}$ & $10 \mathrm{mg}$ & - & - & - & - & $\begin{array}{l}\text { Neuropsychiatric } \\
\text { inventory }\end{array}$ & Yes & $\begin{array}{c}\text { Side effects of } \\
\text { withdrawal, not } \\
\text { efficacy of drug } \\
\text { tested; last } \\
\text { observation } \\
\text { carried forward }\end{array}$ \\
\hline
\end{tabular}

ADAS-cog=Alzheimer's disease assessment scale—cognitive subscale.

CIBIC-plus=Clinician's interview based impression of change with caregiver input.

CGIC=Clinical global impression of change.

J-CGIC=Japanese version of the CGIC.

${ }^{*}$ Refers to the intention to treat population.

†This criterion is satisfied, when several primary end points were calculated without correction for multiplicity and the presented results after correction exceed the significance level of $5 \%$. To adjust for multiple comparisons we used the Bonferroni method. As many trials do not report the number of attempted comparisons, the minimum number of reported independent tests concerning primary end points was used for adjustment. For example, in the study by Burns et al, ${ }^{8}$ two dose groups of donepezil and two primary outcome measures were specified: ADAS-cog and CIBIC-plus. Therefore four comparisons were assumed for Bonferroni adjustment, leading to a required level of $0.05 / 4=0.0125$. This, in spite of an ambiguous definition of the evaluation procedure for the CIBIC-plus in the original publication, which allowed for much more methods of comparison, all of which are mentioned in the results section of the study: comparison of means and of fractions, applying various cut-points. Assuming four comparisons, one end point did not reach the adjusted level: the comparison of donepezil $5 \mathrm{mg}$ with placebo on the CIBIC-plus scores $\leq 3(P=0.015)$. The three other results remain significant after adjustment.

‡Data in tables and text, statements in text and abstract or study results, and abstracts of presentations at congresses are discrepant.

Mohs et $\mathrm{al}^{12}$ used as their primary end point the "median time in days to reach clinically evident functional decline," defined as a decline of at least one point in "basic activities of daily living (ADL)" or "instrumental activities of daily living" according to the Alzheimer's disease functional assessment and change scale or an increase in global clinical dementia rating of 1 point or more (all measures compared with baseline). The authors report that investigators were instructed to use these criteria. However, the final decision to remove a patient from the assigned treatment was left to the clinical judgment of the investigator. This is a methodological shortcoming since investigators could employ subjective measures to withdraw patients from the trial. Furthermore, $26 \%$ of placebo patients and 28\% of donepezil patients discontinued the trial prematurely without reaching the predefined end point, which affects the results considerably. A further shortcoming is the restriction to report clinically evident functional decline over a period of only 48 weeks, although the study lasted for 54 weeks. 


\begin{tabular}{|c|c|c|c|c|c|c|c|}
\hline Author and year & Dose & $\begin{array}{l}\text { Imbalance of } \\
\text { groups at } \\
\text { baseline with } \\
\text { regard to }\end{array}$ & $\begin{array}{l}\% \text { of missing patients in } \\
\text { endpoint } \\
\text { analyses-cholinesterase } \\
\text { inhibitor (placebo) }\end{array}$ & $\begin{array}{l}\text { Missing } \\
\text { information in } \\
\text { publication }\end{array}$ & $\begin{array}{c}\text { No correction for multiple } \\
\text { comparisons } \dagger\end{array}$ & $\begin{array}{l}\text { Calculation of } \\
\text { mean values may } \\
\text { bias results }\end{array}$ & Other shortcomings \\
\hline \multicolumn{8}{|l|}{ Rivastigmine } \\
\hline \multirow[t]{2}{*}{ Agid et al $1998^{17}$} & $4 \mathrm{mg}$ & \multirow[t]{2}{*}{-} & CGIC-18 (12) & \multirow{2}{*}{$\begin{array}{c}\text { Baseline } \\
\text { characteristics }\end{array}$} & \multirow[t]{2}{*}{ Correct: no significant result } & \multirow[t]{2}{*}{-} & \multirow[t]{2}{*}{ Analysis of observed cases only } \\
\hline & $6 \mathrm{mg}$ & & CGIC-23 (12) & & & & \\
\hline \multirow[t]{2}{*}{$\begin{array}{l}\text { Corey-Bloom et al } \\
1998^{18}\end{array}$} & $1-4 \mathrm{mg}$ & & \multirow[t]{2}{*}{-} & \multirow[t]{2}{*}{-} & \multirow[t]{2}{*}{-} & $\begin{array}{l}\text { ADAS-cog } \\
\text { CIBIC-plus }\end{array}$ & \multirow{2}{*}{$\begin{array}{c}\text { Different dropout-rates } \\
(\mathrm{P}<0.05): \\
\text { placebo } 16 \% \\
6-12 \mathrm{mg}: 35 \%\end{array}$} \\
\hline & $6-12 \mathrm{mg}$ & Sex & & & & PDS & \\
\hline \multirow[t]{2}{*}{ Forette et al $1999^{19}$} & $\begin{array}{l}\text { 6-12 mg } \\
\text { twice daily }\end{array}$ & \multirow[t]{2}{*}{-} & $\begin{array}{c}\text { ADAS-cog and CIBIC-plus } \\
-49(21)\end{array}$ & \multirow[t]{2}{*}{$\begin{array}{c}\text { Baseline } \\
\text { characteristics }\end{array}$} & \multirow[t]{2}{*}{ Correct: no significant result } & \multirow[t]{2}{*}{ ADAS-cog } & \multirow{2}{*}{$\begin{array}{l}\text { Analysis of observed cases } \\
\text { only; no a priori defined } \\
\text { primary end point }\end{array}$} \\
\hline & $\begin{array}{l}6-12 \mathrm{mg} \\
\text { thrice daily }\end{array}$ & & $\begin{array}{l}\text { ADAS-cog and CIBIC-plus } \\
\qquad-38(21)\end{array}$ & & & & \\
\hline \multirow[t]{2}{*}{ Rösler et al $1999^{20}$} & $1-4 \mathrm{mg}$ & \multirow[t]{2}{*}{-} & CIBIC-plus-4 (4) & \multirow{2}{*}{$\begin{array}{c}\text { Baseline } \\
\text { characteristics } \\
\text { per group }\end{array}$} & \multirow[t]{2}{*}{ Correct: 2 significant results } & \multirow{2}{*}{$\begin{array}{l}\text { ADAS-cog } \\
\text { CIBIC-plus } \\
\text { PDS }\end{array}$} & \multirow{2}{*}{$\begin{array}{c}\text { Different dropout-rates } \\
(\mathrm{P}<0.05): \\
\text { placebo } 13 \% \\
6-12 \mathrm{mg}: 33 \%\end{array}$} \\
\hline & 6-12 mg & & CIBIC-plus-10 (4) & & & & \\
\hline Potkin et al $2001^{21}$ & $3-9 \mathrm{mg}$ & - & - & $\begin{array}{c}\text { Baseline } \\
\text { characteristics } \\
\text { not complete }\end{array}$ & - & - & $\begin{array}{l}\text { Trial is part of an unpublished } \\
\text { multicentre trial, No of patients } \\
\text { too small }\end{array}$ \\
\hline \multicolumn{8}{|l|}{ Galantamine } \\
\hline \multirow[t]{2}{*}{$\begin{array}{l}\text { Raskind et al } \\
2000^{22}\end{array}$} & $24 \mathrm{mg}$ & \multirow[t]{2}{*}{-} & $\begin{array}{l}\text { ADAS-cog-5 (3) } \\
\text { CIBIC-plus-12 (8) }\end{array}$ & \multirow[t]{2}{*}{-} & \multirow[t]{2}{*}{ Correct: 3 significant results } & \multirow[t]{2}{*}{ ADAS-cog } & \multirow{2}{*}{$\begin{array}{c}\text { Different dropout rates } \\
(\mathrm{P}<0.05): \\
\text { placebo } 19 \% \\
24 \mathrm{mg}: 32 \% \\
32 \mathrm{mg}: 42 \% \text {; last } \\
\text { observation carried forward } \\
\text { (missing values inserted) }\end{array}$} \\
\hline & $32 \mathrm{mg}$ & & $\begin{array}{l}\text { ADAS-cog-7 (3) } \\
\text { CIBIC-plus-19 (8) }\end{array}$ & & & & \\
\hline $\begin{array}{l}\text { Rockwood et al } \\
2001^{23}\end{array}$ & $24-32 \mathrm{mg}$ & - & CIBIC-plus-5 (1) & - & - & ADAS-cog & $\begin{array}{c}\text { Different dropout rates } \\
(\mathrm{P}<0.05): \\
\text { placebo } 10 \% \\
24-32 \mathrm{mg}: 33 \% \text {; last } \\
\text { observation carried forward }\end{array}$ \\
\hline \multirow[t]{3}{*}{ Tariot et al $2000^{24}$} & $8 \mathrm{mg}$ & \multirow[t]{3}{*}{-} & $\begin{array}{l}\text { ADAS-cog-10 (11) } \\
\text { CIBIC-plus-9 (9) }\end{array}$ & \multirow[t]{3}{*}{-} & - & ADAS-cog & $\begin{array}{l}\text { Last observation carried } \\
\text { forward }\end{array}$ \\
\hline & $16 \mathrm{mg}$ & & $\begin{array}{l}\text { ADAS-cog-9 (11) } \\
\text { CIBIC-plus-8 (9) }\end{array}$ & & & & \\
\hline & $24 \mathrm{mg}$ & & $\begin{array}{l}\text { ADAS-cog-7 (11) } \\
\text { CIBIC-plus-7 (9) }\end{array}$ & & & & \\
\hline Wilcock et al $2000^{25}$ & $24 \mathrm{mg}$ & - & CIBIC-plus-6 (6) & - & Correct: 3 significant results & ADAS-cog & $\begin{array}{c}\text { Different dropout rates } \\
(P<0.05): \\
\text { placebo 14\%; }\end{array}$ \\
\hline & $32 \mathrm{mg}$ & & CIBIC-plus-9 (6) & & & & $\begin{array}{l}32 \mathrm{mg}: 25 \% \\
\text { last observation carried } \\
\text { forward }\end{array}$ \\
\hline $\begin{array}{l}\text { Wilkinson et al } \\
2001^{26}\end{array}$ & $18 \mathrm{mg}$ & - & ADAS- $\operatorname{cog}-8 \quad(6)$ & - & - & ADAS-cog & $\begin{array}{l}\text { Different dropout rates } \\
\qquad(p<0.05) \text { : }\end{array}$ \\
\hline & $24 \mathrm{mg}$ & & ADAS- $\operatorname{cog}-2(6)$ & & & & placebo $16 \%$ \\
\hline & $36 \mathrm{mg}$ & & ADAS-cog-6 (6) & & & & $\begin{array}{l}36 \mathrm{mg} \text { : } 48 \% \text {; last } \\
\text { observation carried forward }\end{array}$ \\
\hline
\end{tabular}

ADAS-cog=Alzheimer's disease assessment scale—cognitive subscale.

CIBIC-plus=Clinician's interview based impression of change with caregiver input

CGIC=Clinical global impression of change.

PDS=Progressive deterioration scale.

*Refers to the intention to treat population.

†This criterion is satisfied, when several primary end points were calculated without correction for multiplicity and the presented results after correction exceed the significance level of $5 \%$. To adjust for multiple comparisons we used the Bonferroni method. As many trials do not report the number of attempted comparisons, the minimum number of reported independent tests concerning primary end points was used for adjustment. For example, in the study by Burns et al, ${ }^{8}$ two dose groups of donepezil and two primary outcome measures were specified: ADAS-cos and CIBIC-plus. Therefore four comparisons were assumed for Bonferroni adjustment, leading to a required level of $0.05 / 4=0.0125$. This, in spite of an ambiguous definition of the evaluation procedure for the CIBIC-plus in the original publication, which allowed for much more methods of comparison, all of which are mentioned in the results section of the study: comparison of means and of fractions, applying various cut-points. Assuming four comparisons, one end point did not reach the adjusted level: the comparison of donepezil 5 mg with placebo on the CIBIC-plus scores $\leq 3(P=0.015)$. The three other results remain significant after adjustment.

The AD2000 Collaborative Group ${ }^{15}$ used as its primary end points entry to institutional care and, similarly to Mohs et al, ${ }^{12}$ progression of disability. One important methodological flaw is that the duration of the study was not defined in advance. In addition, the results are presented for the combined groups receiving $5 \mathrm{mg}$ and $10 \mathrm{mg}$ donepezil, although groups should have been tested separately. Therefore this study can neither be used as a proof of inefficacy nor as a proof of efficacy of donepezil.

Holmes et $\mathrm{al}^{16}$ report that patients with Alzheimer's disease and neuropsychiatric symptoms were treated with open label donepezil for 12 weeks. During this treatment phase, patients with poor compliance, adverse events, and deterioration of neuropsychiatric symptoms or cognitive capacity were excluded. The remaining patients were randomised (double blind) between continuation of treatment and withdrawal of drug. The results show a negative effect of withdrawal of donepezil: neuropsychiatric symptoms increased when the drug was withdrawn. However, side effects of drug withdrawal are no proof for the efficacy of donepezil. 
Table 3 Patients with adverse events in the donepezil and placebo groups (actual data because testing for significance is not appropriate for rare effects owing to insufficient power)

\begin{tabular}{|c|c|c|c|c|c|c|c|c|c|c|}
\hline \multicolumn{4}{|l|}{ Characteristics of trial } & \multicolumn{7}{|c|}{$\%$ of patients with adverse events on cholinesterase inhibitor (placebo) } \\
\hline Study & Dose & $\begin{array}{c}\text { No of } \\
\text { patients } \\
\text { taking } \\
\text { cholinesterase } \\
\text { inhibitor }\end{array}$ & $\begin{array}{l}\text { No of } \\
\text { patients } \\
\text { taking } \\
\text { placebo }\end{array}$ & Diarrhoea & Nausea & Vomiting & $\begin{array}{l}\text { Weight loss or } \\
\text { anorexia }\end{array}$ & Insomnia & $\begin{array}{c}\text { Urinary } \\
\text { tract } \\
\text { infection }\end{array}$ & Other adverse events \\
\hline \multicolumn{11}{|l|}{ Donepezil } \\
\hline \multirow[t]{3}{*}{ Rogers et al $1996^{5}$} & $1 \mathrm{mg}$ & 42 & 40 & $0(3)$ & $7(5)$ & & - & - & $2(5)$ & - \\
\hline & $3 \mathrm{mg}$ & 40 & & $3(3)$ & $0(5)$ & & - & - & $8(5)$ & - \\
\hline & $5 \mathrm{mg}$ & 39 & & $10(3)$ & $10(5)$ & & - & - & $3(5)$ & - \\
\hline \multirow[t]{2}{*}{ Rogers et al $1998 a^{6}$} & $5 \mathrm{mg}$ & 157 & 153 & $6(3)$ & $7(8)$ & $3(5)$ & $2(2)$ & $8(5)$ & $6(13)$ & - \\
\hline & $10 \mathrm{mg}$ & 158 & & $13(3)^{*}$ & $22(8)^{*}$ & $6(5)$ & $5(2)$ & $18(5)^{*}$ & $4(13)$ & - \\
\hline \multirow[t]{2}{*}{ Rogers et al $1998 b^{7}$} & $5 \mathrm{mg}$ & 154 & 162 & $9(7)$ & $4(4)$ & $3(2)$ & $2(2)$ & - & - & Muscle cramps: $6(1)^{\star}$ \\
\hline & $10 \mathrm{mg}$ & 157 & & $17(7)^{\star}$ & $17(4)^{*}$ & $10(2)^{*}$ & $7(2)^{*}$ & - & - & $\begin{array}{l}\text { Muscle cramps: } 8(1)^{\star} \\
(10 \mathrm{mg}) \text { fatigue: } 8(2)^{*}\end{array}$ \\
\hline \multirow[t]{2}{*}{ Burns et al $1999^{8}$} & $5 \mathrm{mg}$ & 271 & 274 & $10(4)^{*}$ & $7(7)$ & $4(4)$ & $4(1)$ & $7(4)$ & - & - \\
\hline & $10 \mathrm{mg}$ & 273 & & $16(4)^{*}$ & $24(7)^{\star}$ & $16(4)^{\star}$ & $8(1)^{*}$ & $8(4)^{*}$ & - & - \\
\hline Greenberg et al $2000^{9} \dagger$ & $5 \mathrm{mg}$ & $\mathrm{N} / \mathrm{A}$ & $\mathrm{N} / \mathrm{A}$ & - & - & - & - & - & - & - \\
\hline Homma et al $2000^{10}$ & $5 \mathrm{mg}$ & 136 & 132 & $4(3)$ & $4(1)$ & $1(2)$ & $1(2)$ & - & - & Cold syndrome: 7 (2) \\
\hline Feldman et al $2001^{11}$ & $10 \mathrm{mg}$ & 144 & 146 & $13(5)^{*}$ & $7(4)$ & 7 (3) & $7(4)$ & - & $6(4)$ & $\begin{array}{l}\text { Headache: } 12(4)^{\star} \\
\text { Arthralgia: } 7(1)^{\star}\end{array}$ \\
\hline Mohs et al $2001^{12}$ & $10 \mathrm{mg}$ & 214 & 217 & $17(5)^{*}$ & $9(4)^{*}$ & - & $6(4)^{*}$ & $8(3)$ & $13(7)^{*}$ & $\begin{array}{l}\text { Headache: } 9 \text { (3) } \\
\text { Dyspepsia: } 6 \text { (1) }\end{array}$ \\
\hline Tariot et al $2001^{13}$ & $10 \mathrm{mg}$ & 103 & 105 & $15(10)$ & $9(4)$ & $15(14)$ & $19(10)^{*}$ & - & $16(20)$ & Peripheral oedema: $24(13)^{\star}$ \\
\hline Winblad et al $2001^{14}$ & $10 \mathrm{mg}$ & 142 & 144 & $7(7)$ & $11(9)$ & - & - & $10(7)$ & $6(7)$ & Vertigo: $8(2)^{*}$ \\
\hline $\begin{array}{l}\text { AD2000 Collaborative } \\
\text { Group } 2004^{15}\end{array}$ & $\begin{array}{c}5 \mathrm{mg} \text { or } \\
10 \mathrm{mg}\end{array}$ & 283 & 283 & - & - & - & - & - & - & - \\
\hline Holmes et al $2004^{16}$ & $10 \mathrm{mg}$ & 41 & 55 & - & - & - & - & - & - & - \\
\hline \multicolumn{11}{|l|}{$\mathrm{N} / \mathrm{A}=$ not applicable. } \\
\hline
\end{tabular}

\section{Adverse events of cholinesterase inhibitors}

As shown in tables 3 and 4, donepezil, rivastigmine, and galantamine caused a broad spectrum of adverse eventsnausea, vomiting, diarrhoea, and weight loss were the most common. The tables show the proportions of adverse events observed in patients in whom the difference between the cholinesterase inhibitor and placebo reached significance at the $5 \%$ level.

As adverse events are typical for cholinesterase inhibitors, they can affect the efficiency of blinding, because the raters might be able to guess the patient's treatment.

\section{Discussion}

The scientific basis for recommending donepezil, rivastigmine, or galantamine as preferred treatment for patients with Alzheimer's disease is questionable because minimal benefits were measured on rating scales and the methodological quality of the available trials was poor.

Nineteen out of 22 randomised controlled trials evaluating the efficacy of donepezil, rivastigmine, and galantamine show significant differences between treatment groups and placebo, indicating a beneficial effect of cholinesterase inhibitors, but the differences are rather moderate. The gains of 1.5-3.9 points in cognitive function, as measured with the Alzheimer's disease assessment scale, fall below the 4 points that a panel of experts from the US Food and Drug Administration proposed as the minimum of a clinically important effect. ${ }^{35}$ However, the FDA's assumption that 4 points on the Alzheimer's disease assessment scale is clinically relevant is an expert opinion and presumably not evidence based.
The results on the clinician's interview based impression of change with caregiver input scale, measuring the global function of patients, are moderate as well. The reported differences of 0.26-0.54 points are smaller than the allowed variation for one patient who can only get full scores. Also, the retest reliability of the scale is reported to range from 0.4 points to 0.6 points. ${ }^{36}$

Owing to several methodological shortcomings, the validity of the reported small findings seems to be limited. Missing rigour might have led to an overestimation of beneficial effects. On the other hand, the trials provide clear evidence for considerable adverse events.

\section{Comparison with other studies}

The results of our review are in contrast to numerous publications that support the use of cholinesterase inhibitors. The reason for this discrepancy can be explained by differences in assessment criteria for the methodological quality of the trials. For example, the Cochrane systematic review on donepezil ${ }^{37}$ reports clinical efficacy of donepezil despite reporting the fact that only three of the included studies describe the method of randomisation in sufficient detail and that dropout rates were considerable. In the Cochrane review on galantamine, ${ }^{38}$ the randomisation procedure was the sole indicator of methodological quality of the included trials, and the higher rates of dropouts in patients treated with galantamine did not lead to a different interpretation of results. Also, dropout rates up to $35 \%$ did not influence conclusions in the systematic review on rivastigmine by Birks et al. ${ }^{39}$ When summing up the three Cochrane reviews on cholinesterase inhibitors, it becomes apparent that their conclusions have been drawn without a comprehensive assessment of the methodological quality of the trials. The same problems are 
Table 4 Patients with adverse events in the trials on rivastigmine and galantamine (actual data because testing for significance is not appropriate for rare effects because of insufficient power)

No of patients

\begin{tabular}{|c|c|c|c|c|c|c|c|c|c|}
\hline \multirow[b]{2}{*}{ Study } & \multirow[b]{2}{*}{ Dose } & & \multirow[b]{2}{*}{ Diarrhoea } & \multirow[b]{2}{*}{ Nausea } & \multirow[b]{2}{*}{ Vomiting } & \multirow[b]{2}{*}{$\begin{array}{l}\text { Weight loss } \\
\text { or anorexia }\end{array}$} & \multirow[b]{2}{*}{ Dizziness } & \multirow[b]{2}{*}{$\begin{array}{c}\text { Other adverse events } \\
\text { colsep }=" 0 "\end{array}$} \\
\hline & & Cholinesterase-inhibitor & Placebo & & & & & & \\
\hline \multicolumn{10}{|c|}{ Rivastigmine colsep="0" } \\
\hline \multirow[t]{2}{*}{ Agid $1998^{17}$} & $4 \mathrm{mg}$ & 136 & 133 & $7(2)^{*}$ & $17(6)^{\star}$ & $10(3)^{*}$ & - & $6(7)$ & - colsep =" $0 "$ \\
\hline & $6 \mathrm{mg}$ & 133 & & $12(2)^{*}$ & $31(6)^{*}$ & $18(3)^{*}$ & - & $20(7)^{*}$ & - colsep=" 0 " \\
\hline \multirow[t]{2}{*}{ Corey-Bloom $1998 \dagger^{18}$} & $1-4 \mathrm{mg}$ & 233 & 235 & - & $8(3)^{*}$ & $5(2)^{*}$ & - & $8(4)$ & $\begin{array}{c}\text { Dyspepsia: } 6(1)^{\star} \\
\text { Sinusitis: } 1(1) \\
\text { colsep=" } 0^{\prime \prime}\end{array}$ \\
\hline & 6-12 mg & 231 & & - & $20(3)^{*}$ & $16(2)^{*}$ & - & $14(4)^{*}$ & $\begin{array}{l}\text { Dyspepsia: } 5(1)^{\star} \\
\text { Sinusitis: } 4(1)^{*} \\
\text { colsep }=" 0^{\prime \prime}\end{array}$ \\
\hline \multirow[t]{2}{*}{ Forette $1999^{19}$} & $\begin{array}{c}6-12 \mathrm{mg} \\
\text { twice daily }\end{array}$ & 45 & 24 & - & $58(8)^{*}$ & $38(4)^{*}$ & $18(0)^{*}$ & $27(0)^{*}$ & $\begin{array}{l}\text { Headache: } 16 \text { (4) } \\
\text { colsep }=" 0^{\prime \prime}\end{array}$ \\
\hline & $\begin{array}{l}6-12 \mathrm{mg} \\
\text { thrice daily }\end{array}$ & ly & & - & $58(8)^{\star}$ & $31(4)^{*}$ & $16(0)^{*}$ & $9(0)$ & $\begin{array}{l}\text { Headache: } 20(4)^{\star} \\
\text { colsep }=" 0^{\prime \prime}\end{array}$ \\
\hline \multirow[t]{2}{*}{ Rösler 199920 } & $1-4 \mathrm{mg}$ & 243 & 239 & $10(9)$ & $17(10)^{\star}$ & $8(6)$ & $3(2)$ & $10(7)$ & $\begin{array}{l}\text { Headache: } 7(8) \\
\text { colsep }=" 0^{\prime \prime}\end{array}$ \\
\hline & 6-12 mg & 243 & & $17(9)^{\star}$ & $50(10)^{*}$ & $34(6)^{*}$ & $14(2)^{*}$ & $20(7)^{*}$ & $\begin{array}{l}\text { Headache: } 19(8)^{\star} \\
\text { colsep=" } 0^{\prime \prime}\end{array}$ \\
\hline Potkin $2001^{21}$ & 3-9 mg & 20 & 7 & - & - & - & - & - & - colsep $=" 0^{\prime \prime}$ \\
\hline \multicolumn{10}{|c|}{ Galantamine colsep=" $0^{\prime \prime}$} \\
\hline \multirow[t]{2}{*}{ Raskind $2000^{22}$} & $24 \mathrm{mg}$ & 212 & 213 & $12(10)$ & $37(13)^{*}$ & $21(8)^{*}$ & $12(5)^{*}$ & $14(11)$ & - colsep=" 0 " \\
\hline & $32 \mathrm{mg}$ & 211 & & $19(10)^{*}$ & $44(13)^{*}$ & $26(8)^{*}$ & $11(5)^{*}$ & $19(11)^{*}$ & - colsep=" 0 " \\
\hline Rockwood $2001^{23}$ & $24-32 \mathrm{mg}$ & 261 & 125 & - & $32(11)^{\star}$ & $15(4)^{*}$ & $12(2)^{*}$ & $15(4)^{*}$ & $\begin{array}{c}\text { Agitation: } 6(1)^{\star} \\
\text { Somnolence: } 8(1)^{\star} \\
\text { colsep="0" }\end{array}$ \\
\hline \multirow[t]{3}{*}{ Tariot $2000^{24}$} & $8 \mathrm{mg}$ & 140 & 286 & $5(6)$ & $6(5)$ & $4(1)$ & $6(3)$ & - & - colsep=" 0 " \\
\hline & $16 \mathrm{mg}$ & 279 & & $12(6)^{\star}$ & $13(5)^{*}$ & $6(1)^{*}$ & $7(3)$ & - & - colsep=" 0 " \\
\hline & $24 \mathrm{mg}$ & 273 & & $6(6)$ & $17(5)^{\star}$ & $10(1)^{*}$ & $9(3)^{*}$ & - & - colsep="0" \\
\hline \multirow[t]{2}{*}{ Wilcock $2000^{25}$} & $24 \mathrm{mg}$ & 220 & 215 & $7(7)$ & $37(12)^{\star}$ & $20(4)^{*}$ & $8(1)^{\star}$ & $11(5)^{*}$ & $\begin{array}{l}\text { Anorexia: } 10(0)^{\star} \\
\text { colsep }=" 0 "\end{array}$ \\
\hline & $32 \mathrm{mg}$ & 218 & & $13(7)^{\star}$ & $40(12)^{*}$ & $17(4)^{*}$ & $5(1)^{*}$ & $12(5)^{*}$ & $\begin{array}{l}\text { Anorexia: } 11(0)^{*} \\
\text { colsep=" } 0^{\prime \prime}\end{array}$ \\
\hline \multirow[t]{3}{*}{ Wilkinson $2001^{26}$} & $18 \mathrm{mg}$ & 88 & 87 & $2(2)$ & $17(3)^{\star}$ & $17(5)^{*}$ & - & $5(3)$ & $\begin{array}{l}\text { Headache: } 6 \text { (5) } \\
\text { colsep="0" }\end{array}$ \\
\hline & $24 \mathrm{mg}$ & 56 & & $5(2)$ & $18(3)^{\star}$ & $7(5)$ & - & $4(3)$ & Headache: 11 (5) \\
\hline & $36 \mathrm{mg}$ & 54 & & $4(2)$ & $37(3)^{\star}$ & $17(5)^{\star}$ & - & $7(3)$ & Headache: $15(5)^{\star}$ \\
\hline
\end{tabular}

- =Not reported.

*Differences reach significance $(\mathrm{P}<0.05)$.

†Data shown represent the maintenance phase of the trial (week 8-26).

found in meta-analyses. Whitehead et $\mathrm{al}^{40}$ performed a meta-analysis of individual patients' data from randomised controlled trials on donepezil, and Ritchie et $\mathrm{al}^{41}$ carried out a metaanalysis of published data from randomised controlled trials on donepezil, rivastigmine, and galantamine. No attempt was made in either meta-analysis to consider the quality of the included trials. Since all individual trials show considerable methodological shortcomings, the results of both meta-analyses are questionable as well. The same lack of assessment of methodological quality of the reviewed trials is found in the review of the American Academy of Neurology.

\section{Conclusions}

Clinicians often argue that cholinesterase inhibitors have an effect in a subgroup of only $10-20 \%$ of patients with Alzheimer's disease. As this subgroup cannot be identified in advance, they conclude that all patients with Alzheimer's disease should be treated. From a scientific point of view, three replies seem justified. Firstly, this observation could also be due to a placebo effect. Secondly, if there are subgroups of patients who benefit research should focus on the definition of responders. Thirdly, if the efficacy of the drugs is tested at the level of individual patients, clear reassessment procedures are needed for clinical practice.

Acknowledgements: We thank Michael M Kochen, Göttingen, for constant support and critical advice and Heinz-Peter Romberg, Bonn, for continuous collection of information on cholinesterase inhibitors. We also thank the members of the German Association of General Practitioners (DEGAM) for their interest and precious discussion of the subject on several occasions.

Contributors: HK, TZ and HPBB developed the design of this review, performed the literature search, analysed and interpreted the trials. The article was written by $\mathrm{HK}$ and revised repeatedly by TZ, HPBB, and HvdB. The final version was approved by HvdB. HK is the guarantor.

\section{What is already known on this topic}

It is generally assumed that several randomised controlled trials have proved the beneficial effect of cholinesterase inhibitors in patients with Alzheimer's disease on cognitive and global outcome measures

Numerous "evidence based reviews" support this assumption

\section{What this study adds}

Recommendations for the use of cholinesterase inhibitors do not seem to be evidence based

Benefits measured on rating scales were minimal

The methodological quality of the available trials was poor 
Funding: None.

Competing interests: None declared.

Ethics approval: Not required.

1 National Institute for Clinical Excellence (NICE). Guidance on the use of donepezil, rivastigmine and galantamine for the treatment of Alzheimer's disease. London: NICE, 2001.

2 Doody RS, Stevens JC, Beck C, Dubinsky RM, Kaye JA, Gwyther L, et al. Practice parameter: management of dementia (an evidence-based review). Report of the Quality Standards Subcommittee of the American Academy of Neurology. Neurology 2001;56:1154-66.

3 Fritze J. Prescription of psychotropic drugs: results and commentaries to the drug prescription report 2004 [in German]. Psychoneurology 2005;31:46-52.

4 Moher D, Schulz KF, Altman DG for the CONSORT Group. The CONSORT statement: revised recommendations for improving the quality of reports of parallel-group randomized trials. Ann Intern Med 2001;134:657-62.

5 Rogers SL, Friedhoff LT. The efficacy and safety of donepezil in patients with Alzheimer's disease: results of a US multicentre, randomized, double-blind, Alzheimer's disease: results of a 1 . multicent

6 Rogers SL, Doody RS, Mohs RC, Friedhoff LT, and the Donepezil Study Group. Donepezil improves cognition and global function in Alzheimer disease: a 15-week double-blind, placebo-controlled study. Arch Intern Med 1998;158:1021-31. (Roger 1998a in table 3.)

7 Rogers SL, Farlow MR, Doody RS, Mohs R, Friedhoff LT, and the Donepezil Study Group. A 24-week, double-blind, placebo-controlled trial of donepezil in patients with Alzheimer's disease. Neurology 1998;50:136-45. (Rogers 1998b in table 3.)

8 Burns A, Friedhoff LT, Gauthier S, Hecker J, Moller HJ, Petit H, et al. The effects of donepezil in Alzheimer's disease-results from a multinational trial. Dement Geriat Cogn Disord 1999;10:237-44.

9 Greenberg SM, Tennis MK, Brown LB, Gomez-Isla T, Hayden DL, Schoenfeld DA, et al. Donepezil therapy in clinical practice: a randomised crossover study. Arch Neurol $2000 \cdot 57 \cdot 94-9$

10 Homma A, Takeda M, Imai Y, Udaka F, Hasegawa K, Kameyama M, et al. Clinical efficacy and safety of donepezil on cognitive and global function in patients with Alzheimer's disease: a 24-week, multicenter, double-blind, placebo-controlled study in Japan Dement Geriatr Cogn Disord 2000;11:299-313.

11 Feldman H, Gauthier S, Hecker J, Vellas B, Subbiah P, Whalen E, and the Donepezi MSAD Study Investigators Group. A 24-week, randomized, double-blind study of donepezil in moderate to severe Alzheimer's disease. Neurology 2001;57:613-20.

12 Mohs RC, Doody RS, Morris JC, Ieni JR, Rogers SL, Perdomo CA, et al. A 1-year, placebo-controlled preservation of function survival study of donepezil in $\mathrm{AD}$ patients. Neurology 2001;57:481-8.

13 Tariot PN, Cummings JL, Katz IR, Mintzer, J, Perdomo CA, Schwam EM, Whalen E, and the Donepezil Nursing Home Study Investigators Group. A randomized, double-blind, placebo-controlled study of the efficacy and safety of donepezil in patients with Alzheimer's disease in the nursing home setting. J Am Geriatr Soc 2001;49:1590-9.

14 Winblad B, Engedal K, Soininen H, Verhey F, Waldemar G, Wimo A, et al. A 1-year, randomized, placebo-controlled study of donepezil in patients with mild to moderate AD. Neurology 2001;57:489-95.

15 AD2000 Collaborative Group. Long-term donepezil treatment in 565 patients with Alzheimer's disease (AD2000): randomised double-blind trial. Lancet 2004;363:210515.

16 Holmes C, Wilkinson D, Dean C, Vethanayagam S, Olivieri S, Langley A, et al. The efficacy of donepezil in the treatment of neuropsychiatric symptoms in Alzheimer disease Neurology $2004,63: 2149$.

17 Agid Y, Dubois B, on behalf of the International Rivastigmine Investigators, Anand R, Agid Y, Dubois B, on behalf of the International Rivastigmine Investigators, Anand R,
Gharabawi G. Efficacy and tolerability of rivastigmine in patients with dementia of the Gharabawi G. Efficacy and tolerability of rivastigmine in

18 Alzheimer type. Curr Ther Res Clin Exp 1998;59:837-45. trial evaluating the efficacy and the safety of ENA 713 (rivastigmine tartrate), a new acetylcholinesterase inhibitor, in patients with mild to moderately severe Alzheimer's disease. Int J Geriatr Psychopharmacol 1998;1:55-65.

19 Forette F, Anand R, Gharabawi G. A phase II study in patients with Alzheimer's disease to assess the preliminary efficacy and maximum tolerated dose of rivastigmine (Exelon). Eur J Neurol 1999;6:423-9.

20 Rosler M, Anand R, Cicin-Sain A, Gauthier S, Agid Y, Dal-Bianco P, et al. Efficacy and safety of rivastigmine in patients with Alzheimer's disease: international randomised safety of rivastigmine in patients with
controlled trial. $B M J 1999 ; 318: 633-40$.

21 Potkin SG, Anand R, Fleming, K, et al. Brain metabolic and clinical effects of rivastigmine in Alzheimer's disease. Int J Neuropsychopharmacol 2001;4:223-30.
22 Raskind MA, Peskind ER, Wessel T, Yuan W, and the Galantamine USA-1 Study Group A 6-month randomized, placebo-controlled trial with a 6-month extension. Neurology 2000;54:2261-8.

23 Rockwood K, Mintzer J, Truyen L, Wessel T, Wilkinson D. Effects of a flexible galantamine dose in Alzheimer's disease: a randomized, controlled trial.J Neurol Neurosurg Psychiatry 2001;71:589-95.

24 Tariot PN, Solomon PR, Morris JC, Kershaw P, Lilienfeld S, Ding C. A 5-month, randomized, placebo-controlled trial of galantamine in AD. Neurology 2000;54:226976 .

25 Wilcock GK, Lilienfeld S, Gaens E on behalf of the Galantamine International-1 Study Group. Efficacy and safety of galantamine in patients with mild to moderate Alzheimer's disease: multicentre randomised controlled trial. BMJ 2000;321:1-7.

26 Wilkinson D, Murray J, in collaboration with the Galantamine Research Group. Galantamine: a randomized, double-blind, dose comparison in patients with Alzheimer's disease. Int J Geriatr Psychiatry 2001;16:852-7.

27 McKhann G, Drachman D, Folstein M, Katzman R, Price D, Stadlan EM. Clinical Diagnosis of Alzheimer's Disease: report of the NINCDS/ADRDA work group under the auspices of the Department of Health and Human Services Task Force on Alzheimer's Disease. Neurology 1984;34:939-44.

28 Rosen WG, Mohs RC, Davis KL. A new rating scale for Alzheimer's disease. Am J Psychiatry 1984;141:1356-64.

29 Reisberg B, Ferris SH. CIBIC-Plus Interview Guide. East Hanover, NJ: Sandoz Pharmaceuticals Corporation, 1994

30 Cummings JL, Mega M, Gray K, Rosenberg-Thompson S, Carusi DA, Gornbein J. The Neuropsychiatric Inventory: Comprehensive assessment of psychopathology in dementia. Neurology 1994;44:2308-14.

31 Wood S, Cummings JL, Hsu MA, Barclay TB, Wheatley MV, Yarema KT, et al. The use of the neuropsychiatric inventory in nursing home residents: characterization and measurement. Am J Geriatr Psychiatry 1999;8:75-83.

32 Brane G, Gottfries CG, Winblad B. The Gottfries-Brane-Steen scale: validity, reliability and application in anti-dementia drug trials. Dement Geriatr Cogn Disord 2001;12:1-14 33 Guy W, ed. Clinical global impressions (CGI). In: ECDEU assessment manual for psychopharmacology. Rockville, MD: National Institutes for Mental Health 1976;207-12.

34 Dejong R, Osterlund OW, Roy GW. Measurement of quality-of-life changes in patients with Alzheimer's disease. Clin Ther 1989;11:545-54.

35 Peripheral and Central Nervous System Drugs Advisory Committee Meeting, July 7, 1989. Rockville, MD: Department of Health and Human Services, Public Health Service, Food and Drug Administration, 1989:227.

36 Florack C, Franz H, Kaiser T, Sawicki PT. The value of donepezil in the drug therapy of Alzheimer's disease [in German]. Offizielles Mitteilungsblatt der KV Sachsen-Anhalt 2002:1-3.

37 Birks JS, Harvey R. Donepezil for dementia due to Alzheimer's disease. Cochrane Database Syst Rev 2003;(3):CD001190.

38 Olin J, Schneider L. Galantamine for Alzheimer's disease. Cochrane Database Syst Reo 2002;(3):CD001747.

39 Birks J, Grimley Evans J, Iakovidou V, Tsolaki M. Rivastigmine for Alzheimer's disease. Cochrane Database Syst Rev 2000;(4):CD001191.

40 Whitehead A, Perdomo C, Pratt RD, Birks J, et al. Donepezil for the symptomatic treatment of patients with mild to moderate Alzheimer's disease: a meta-analysis of individual patient data from randomised controlled trials. Int I Geriatr Psychiatry 2004:19:624-33.

41 Ritchie CW, Ames D, Clayton T, Lai R. Metaanalysis of randomized trials of the efficacy and safety of donepezil, galantamine, and rivastigmine for the treatment of Alzheimer disease. Am J Geriatr Psychiatry 2004;12:358-69.

(Accepted 29 April 2005)

bmj.com 2005;331:321

Department of Primary Medical Care, Center of Psychosocial Medicine, University Medical Center Hamburg-Eppendorf, Martinistraße 52, D-20246 Hamburg, Germany

Hanna Kaduszkiewicz research fellow

Thomas Zimmermann research fellow

Hans-Peter Beck-Bornholdt professor

Hendrik van den Bussche director

Corresponding author: H Kaduszkiewicz kaduszki@uke.uni-hamburg.de 